Thematic course: Antioxidant properties of aqueous media with molecular hydrogen. Part 2.

\title{
Justification for the use of "Aquaspectrum" containers for saturation of aqueous media with active hydrogen using a biochemical indicator of total antioxidant activity
}

\author{
(C) Anatoly A. Lapin, ${ }^{1 *^{+}}$and Ashot P. Khachatryan ${ }^{2}$ \\ ${ }^{1}$ Department "Aquatic Bioresources and Aquaculture". Kazan State Power Engineering University. \\ Krasnoselskaya St., 51. Kazan, 420066. Republic of Tatarstan. Russia. \\ Phone:+7 (843) 519-42-67.E-mail: lapinanatol@mail.ru \\ ${ }^{2}$ LLC International Academy of Health. Clinic of hydrogen medicine of Professor Khachatryan. \\ Vatutina St., 4. Novosibirsk, 630075, Russia. Phone: +7 (917)-284-47-77 \\ E-mail: interacadem@mail.ru
}

\begin{abstract}
*Supervising author; ${ }^{+}$Corresponding author Keywords: antioxidant activity, total antioxidant activity, coulometric method of analysis, hydrogen, water, activation, magnesium alloys.
\end{abstract}

\begin{abstract}
The article presents the results of a biochemical study of aqueous environments with molecular hydrogen by antioxidant activity. Activated hydrogen has selective antioxidant activity against dangerous free radicals for the human body and animals. In addition, its anti-inflammatory, anti-apoptotic, anti-allergic properties were found and it stimulates energy metabolism in cells. This problem is currently relevant due to the great interest in activated hydrogen as an antioxidant over the past ten years, but its quantitative metabolic parameters have not yet been assessed at a sufficient scientific level. The total antioxidant activity of aqueous systems saturated with hydrogen was studied using coulometric analysis. It has been shown that their total antioxidant activity increases depending on the quality of aqueous media and the operating time of the "Aquaspectr Hydrogen Mug Mug for Activating Water" device: for Arkhyz mineral water, 20 times after 26 minutes of hydrogen saturation, drinking natural oxalis Kristalia with mineral drinking medicinal water DonatMg (in volume ratio) 31 times after 55 minutes and DonatMg mineral drinking medical water 44 times after 28 minutes. The total antioxidant activity was determined using electrically generated bromine, the samples were analyzed on a certified Expert-006 coulometer (Econix-Expert LLC, Russia) according to a certified method. In the work it was shown that saturation of water systems, in particular mineral and drinking water, by the method of hydrogen evolution on the surface of containers from environmentally friendly magnesium alloys, can be quite an effective way to activate various liquid media with antioxidants used in environmental medicine. In addition, our results can be useful in solving scientific and technical problems in the development of alternative energy sources.
\end{abstract}

\section{References}

[1] S.V. Chepur, N.P. Pluzhnikov, O.G. Khurtsilava etal. Biological effects of molecular hydrogen and the possibility of its use in clinical practice. Successes of modernbiology. 2017. Vol.137. No.3. P.311-318. (russian)

[2] B.I. Dixon, J. Tang, J.H. Zhang. The evolution of molecularhydrogen a noteworthy potentialtherapy with clinical significance. Med Gas Res. 2013. May 16;3(1):10. Doi: 10.1186/2045-9912-3-10

[3] A.A. Lapin, I.G. Garifullin, V.N. Zelenkov, S.D. Filippov. Antioxidant properties of aqueous media with molecular hydrogen used in tnviromental medicine. Butlerov Communications. 2019. Vol.59. No.8. P.140-146. DOI: $10.37952 / R O I-j b c-02 / 19-59-8-140$

[4] A.A. Lapin, Yu.V. Chugunov, and S.D. Filippov. The total antioxidant activity of the aqueous systems, saturated with hydrogen. Butlerov Communications. 2015. Vol.44. No.12. P.61-66. DOI: 10.37952/ROIjbc-02/15-44-12-61

[5] A.A. Lapin, A.A. Kalayda, S.D. Filippov, V.N. Zelenkov. Biochemical effect sofmolecular hydrogenin aqueoussystems. International Water and Energy Forum - 2018: collection of reports in 2 volumes.

Kazan: Kazan.gos. energ un-t. 2018. Vol.1. 373p. P.81-84. (russian) 
[6] A.A. Lapin, S.D. Filippov, V.N. Zelenkov, A.A. Kalayda. Biochemical effect sofmolecular hydrogenin aqueoussystems. International Scientific and Practical Conference: Water Power Energy Forum 2018 IOP Conf. Series: Earth and Environmental Science 288 (2019) 012054 IOP Publishing doi:10.1088/1755-1315/288/1/012054.

[7] Mug for activating water AquaspectrHydrogenMug $400 \mathrm{ml}$ black. [Electronic resource] - URL: https://health-tehnika.ru/product/kruzhka-dlya-aktivatsii-vody-hydrogen-mug/(date of the application 25.02.2020). (russian)

[8] Mineral water "Kislovodsk healing". [Electronic resource] - URL: http: //minrosvody.blogspot.com/2015/05/blog-post_96.html/_(date of the application 25.02.2020). (russian)

[9] Drinking non-carbonated natural water "Kristaliya". [Electronic resource] - URL: https://www.ozon.ru/category/negazirovannaya-voda-31363/?page=2/ (date of the application 25.02.2020). (russian)

[10] Mineral, drinking, healing water donat $\mathrm{Mg}$ (Donat $\mathrm{Mg}$ ) of the company "DrogaKolinskaZivilskaindustrijad.d.". [Electronic resource] - URL: https://market.yandex.ru/brands-donat-mg/10769842/ (date of the application 25.02.2020). (ruussian)

[11] Mineral, drinking, medicinal-table, sodium bicarbonate, sparkling water "Borjomi" Georgia, company "IDSBorjomiGeorgia".[Electronic resource] - URL: https://zdravcity.ru/p_borzhomi-voda-mineralnajaprirodnaja-lechebno-stolovaja-gidrokarbonatnaja-natrievaja-gazir-but-0-5-p-0091106.htm/ (date of the application 25.02.2020). (russian)

[12] V.N. Zelenkov, A.A. Lapin. MVI-001-44538054-07. Total antioxidant activity. Method of measurement on coulometric analyzer. Research Institute of vegetable growing. Vereya, Moscow region. 2013. 19p. (russian)

[13] TU 9369-141-04868244-07.Routine is the standard pattern. Technical conditions. (russian)

[14] State Pharmacopoeia of the USSR. Iss.2. General methods of analysis. Medicinal plant raw materials. Ministry of health of the USSR. 11th ed., EXT. Moscow: Medicine. 1989. 398p. (russian)

[15] Fashion Esipov D. in statistics. [Electronic resource] - URL: http:// statanaliz.info/metody/opisaniedannyx/56-mod (date of the application 10.06.2019). (russian)

[16] R.K. Kostonyan, G.G. Karamyan, P.I. Ivashkin, M.M. Kalugin, G.A. Martoyan. Perspektivy ispol'zovaniya magniya v kachestve vozobnovlyayemogo istochnika energii. Moscow: Publishing house RAN. 2017. 28p. (russian)

[17] V.I. Kirillov, A.N. Yastrebov. Hydroreacting material for producing hydrogen and a method for its production. Pat. RF 2031834. IPC: C01B3 / 00, C01B3 / 08. (Published on March 27, 1998). (russian)

[18] 3.2. Chemical properties of magnesium. [Electronic resource] - URL: https:// works.doklad.ru/view/

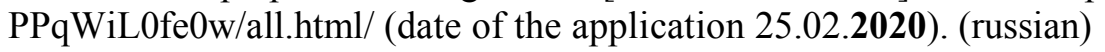

